\title{
Why 'Doing Business' with the World Bank May Be Bad for You
}

\section{Gerard McCormack ${ }^{1}$}

Published online: 30 August 2018

(c) The Author(s) 2018

\begin{abstract}
This paper critically examines the role of law in promoting economic development and argues that the most influential 'law and development' agenda-the World Bank Doing Business (DB) project-is not fit for purpose and should be replaced. The paper argues that the DB project and associated rankings embody a set of ideological and technical preferences whose relationship with economic development is at best uncertain. Context and cultural sensitivity are all important in the 'real' world and reducing complicated matters to a single ranking is not compatible with bringing about genuine improvements in the legal framework for doing business.
\end{abstract}

Keywords Law · Development · World Bank · Doing Business · Credit · Insolvency

\section{Introduction}

This paper subjects the most influential Law and Development agenda currently on the table with policy makers - the World Bank Doing Business (DB) project-to critical attack. It suggests that it is not fit for purpose and should be replaced.

The role of law in promoting economic development has long been a controversial one. ${ }^{1}$ Certain legal systems may be conducive to higher rates of economic development but the necessary causal link between the two is difficult to establish. Nevertheless, the DB project and associated rankings ${ }^{2}$ has sparked the attention of

\footnotetext{
1 On these and related issues, see North (1990); Goodhart (1997); Posner (1998); Dam (2013).

2 See http://www.doingbusiness.org/. The 2018 Doing Business report and other Doing Business annual reports are freely downloadable from the World Bank website-for the 2018 report see http://www.doing business.org/ /media/WBG/DoingBusiness/Documents/Annual-Reports/English/DB2018-Full-Repor t.pdf/. The report was published on 31st October 2017 and the rankings for all economies are benchmarked to June 2017. For recent controversy over Chile's rankings in the Doing Business reports see https://www.worldbank.org/en/news/statement/2018/07/11/world-bank-group-statement-on-externalaudit-of-chiles-rankings-in-doing-business-report.
}

Gerard McCormack

G.McCormack@leeds.ac.uk

1 International Business Law, University of Leeds, Leeds, UK 
politicians and policy makers across the globe. For example, the UK government has committed itself to being among the global top five in the rankings ${ }^{3}$ and the European Commission has used the relatively poor ranking of some EU countries as part of its justification for building a Capital Markets Union. ${ }^{4}$

The DB project stresses the importance of a well-functioning legal and regulatory system in creating an effective market economy and, as a corollary, the deleterious effects that a poor regulatory environment can have on output, employment, investment, productivity, and living standards. The DB project has focused attention on law and development issues; its methodology is fairly transparent and it has produced data sets that are of great benefit to researchers. Nevertheless, the way in which the rankings are compiled encourages countries to 'game' the system. ${ }^{5}$ The rankings embody, explicitly or implicitly, a particular set of preferences, whose relationship with matters of economic development is at best uncertain. Moreover, the DB project largely, if not entirely, mirrors the law on the books which may not necessarily reflect what happens in practice in a particular country. ${ }^{6}$

This paper suggests that the DB project should not survive, at least in its present form, because of the theoretical and methodological deficiencies inherent in its conception and implementation. The 2013 report of an independent review panel commissioned by the World Bank to examine the DB project voiced similar objections and the same has also been said in more polemical tones by charities, aid agencies and media commentators. ${ }^{7}$ This paper however, goes further by digging down into the methodology of particular indicators and into the details of their relationship with a questionable set of normative assumptions. To the extent this has been done in the past, it has been done in the context of the 'Paying Taxes' and 'Employing Workers' indicators. ${ }^{8}$ This paper takes a different tack and examines the 'Getting Credit' and 'Resolving Insolvency' indicators. ${ }^{9}$

The paper has eight sections including this first introductory section. Section 2 looks at the background to the DB project tracing its antecedents back to the law and development movement in the 1960s and more directly to the 'law matters' thesis

\footnotetext{
3 See e.g. UK Insolvency Service (2016a), para. 2.3 which references the Conservative party 2015 election manifesto in this connection.

${ }^{4}$ Capital Markets Action Plan, COM(2015) 468. For reference to the DB rankings see e.g. p 25 of the Action Plan: 'The 2015 World Bank Doing Business Report ranks countries on the strength of their insolvency frameworks on a scale of $0-16$. The EU simple average is 11.6 , which is $5 \%$ below the OECD average for high income countries (12.2). Some Member States score below 8'.

5 The 2016 Doing Business report at p v acknowledges the possibility of gaming: 'Ranking universities often leads them to try to game the system and move resources and effort away from some important but unmeasurable dimensions to the narrower tasks that are tracked and measured'.

6 See generally on differences in outcomes when one measures 'law on the books' as distinct from its application in practice Hallward-Driemeier and Pritchett (2015).

7 See 'Business as usual: World Bank rejects Doing Business reforms', at http://www.brettonwoodspro ject.org/2014/06/business-usual-bank-rejects-business-reforms/ (accessed 20 July 2018) and 'A bad business: Bank divisions on Doing Business revealed', at http://www.brettonwoodsproject.org/2013/10/badbusiness/ (accessed 20 July 2018).

${ }^{8}$ See generally Davis and Kruse (2007); Deakin et al. (2007); Lee et al. (2008); Bakvis (2009); Sarfaty (2009).

9 On a different indicator see Lin and Ewing-Chow (2016).
} 
of elite economists in the 1990s. Section 3 focuses on the influence and esteem of the DB project highlighting the fact that certain governments have established highlevel committees and task forces to improve the position of their countries in the rankings. Section 4 details some of the criticisms levelled at the World Bank project including in the 2013 independent review panel report. ${ }^{10}$ Section 5 examines how the World Bank has responded to these criticisms and changes that it has made in the World Bank methodology as a result. Section 6 focuses on the 'Getting Credit' indicator and its intimate relationship with a host of legal propositions held dear by certain international organisations but whose empirical robustness is more open to doubt. Section 7 does the same for the 'Resolving Insolvency' indicator. Section 8 concludes.

\section{Doing Business and Its Antecedents}

The Doing Business (DB) project has an Ease of Doing Business Index and associated rankings that purport to measure the regulations affecting business in countries throughout the world-regulations that affect business formation and operation. The rankings are premised on the assumption that everyday economic activity in countries is fashioned by laws, regulations and institutional arrangements.

The DB rankings have been issued annually since 2004 in the form of a report published by the World Bank Group. ${ }^{11}$ In its original incarnation, the DB report contained five sets of indicators for 145 economies $^{12}$ whereas the most recent 2017 report includes 11 sets of indicators for 190 economies. ${ }^{13}$ Each economy is ranked on the individual indicators and also in an overall table based on its score across 10 of the 11 indicators. ${ }^{14}$ The reports and rankings are grounded on the notion that smarter business regulation promotes economic growth. This means an effective regulatory environment and a sound financial market infrastructure including straightforward business registration procedures as well as procedures that facilitate the closure of ailing businesses and the restructuring and recovery of potentially profitable ones. In the 2018 report the top ten countries in the overall rankings

\footnotetext{
${ }^{10}$ See Independent Panel Review of the World Bank Doing Business report (Washington DC, World Bank, 2013). The Panel was chaired by Trevor Manuel, the former South African Minister of Finance.

${ }^{11}$ Djankov et al. (2004). For a brief discussion of the background to the project see the statements by the World Bank Chief Economist, Paul Romer, in the Foreword to the 2017 report at p iv and for some more details see Djankov (2016). Professor Romer has now resigned from his World Bank position and for the background to his resignation see https://www.worldbank.org/en/news/statement/2018/07/11/world-bankgroup-statement-on-external-audit-of-chiles-rankings-in-doing-business-report.

${ }^{12}$ The original indicators were starting a business, hiring and firing workers, enforcing contracts, getting credit and closing a business.

${ }^{13}$ See 2018 Doing Business report, p 1 and the Economy Rankings at http://www.doingbusiness.org/ rankings.

${ }^{14}$ See the 2018 Doing Business report, p 11: 'Although Doing Business does not present rankings of economies on the labor market regulation indicators [...] it does present the data for these indicators'. For criticism of the approach previously adopted by the DB reports in relation to labour market regulation see Benjamin and Theron (2009).
} 
are New Zealand followed by Singapore, Denmark, South Korea, Hong Kong SAR, US, UK, US, Norway, Georgia and Sweden. ${ }^{15}$ The rankings however, do not directly measure more general factors that might facilitate doing business such as country's geographical location including proximity to large markets; the quality of the physical infrastructure and the incidence of crime, corruption and internal unrest. 'The focus is deliberately narrow even within the relatively small set of indicators included in Doing Business'. ${ }^{16}$

In drawing up the data, the DB project relies on information from four main sources. Firstly, the relevant laws and regulations themselves as they appear on the statute book and in relevant administrative manuals; secondly, DB respondents in the countries concerned; thirdly, the relevant governments and fourthly, regional staff from the World Bank Group. The DB team conducts extensive consultations with multiple respondents with a view to minimising measurement error. Since the focus is on legal and regulatory arrangements, the respondents are largely legal professionals since these are considered most likely to have the relevant knowledge. Firms are not directly surveyed. ${ }^{17}$

In terms of basic approach, the DB reports and rankings are based on a more sophisticated version of the 'legal origins', 'law and finance' or 'law matters' thesis developed by a leading group of financial economists, including La Porta, Lopez de Silanes, Shleifer and Vishny, in the 1990s. ${ }^{18}$ The intellectual roots stretch even deeper however; certainly as far back at the US 'law and development' movement in the 1960s. The 'law and development' theorists saw development as a process whereby societies would transform along a host of dimensions to become 'modern'. Scholars from a range of disciplines shared the modernisation agenda and inter-disciplinarity was fundamental to the goal of developing a total theory of society. ${ }^{19}$

There was a shared, if tacit, set of assumptions about the relationship between law and development. This has been described as a basic paradigm of 'liberal legalism' grounded in modernisation theory ${ }^{20}$ which suggested that law could be used as a means to promote economic growth. One of the perceived obstacles in the path of modernisation however was the fact that ideas about law in the less developed world were rather formalistic and driven by a set of culturally-inspired attitudes, beliefs, and expectations. ${ }^{21}$ Legal rules were thought to be abstract and rigid and out of touch with social needs and, therefore, they were often ignored in practice. 'As first-wave law and development scholars perceived it, this state of affairs was

\footnotetext{
15 See 2018 Doing Business report, p 4 and see also the following note to the rankings: 'The DB 2018 rankings are benchmarked to June 2017 and based on the average of each economy's distance to frontier (DTF) scores for the 10 topics included in the aggregate ranking'. The evolution of the methodology is explained at pp iv-vi of the 2016 Doing Business report and pp 1-5 of the 2017 report.

16 See the 2018 Doing Business report, p 13.

17 See the 2018 Doing Business report, pp 17-18.

18 See La Porta et al. (1997); La Porta et al. (1998). The first three named authors refine the 'legal origins' thesis and defend it against criticisms in La Porta et al. (2008).

19 See Ohnesorge (2007), p 233 text accompanying fn. 43.

20 See Trubek and Galanter (1974), p 1070.

21 See Trubek (2006).
} 
paradigmatically not modern'. ${ }^{22}$ Blind rule following and unimaginative bureaucratic habits in developing countries were said to prevent the law in the books from realising its potential with the solution being to build a more pragmatic and antiformalist local legal culture. ${ }^{23}$

The enthusiasm of law and development scholars waned however, with harsher and more uncertain economic and political times. ${ }^{24}$ One observer has commented that 'the broader modernization ethos succumbed to realities such as the Vietnam War and the extent to which "modern" Western societies did not themselves fit the model, and as funding for law and development activities dried up'. ${ }^{25}$ These 'law and development' scholars conceded in the early 1970s that the attempts to transplant 'Western' law to developing countries and to use it in the service of development had not fared very well. ${ }^{26}$

With the end of the Cold War and the collapse of the Soviet Union, interest in the Law and Development agenda revived. It took on however, a more formalistic and right-leaning twist in the form of the 'law matters' or 'legal origins' thesis advanced by La Porta, Lopez de Silanes, Shleifer and Vishny et al. ${ }^{27}$ The thesis was developed in response to perceived rent-seeking behaviour by governments in Statecontrolled economies ${ }^{28}$ and was first advanced in the area of investor protection and later extended to encompass creditor rights and legal institutions more generally. According to the thesis, 'law matters' in that legal institutions impact on economic growth. More controversially however, the thesis also asserted that countries that adopted the common law performed better than those with a civil law origin. ${ }^{29}$ The thesis evaluated legal families on the basis of their economic performance and generally the common law came out as superior. The alleged superiority was said to be founded on two propositions. The first proposition was that judges were said to have greater independence under common law rather than under civil law systems and therefore the government had less influence on market developments. The second was that the common law, since it was based on case law rather than on legislative codes, was more responsive to the changing conditions and requirements of society.

\footnotetext{
22 Cohen (2009), p 517.

23 Kennedy (2006).

${ }^{24}$ For a 'law and development' overview see generally Kennedy (2013).

25 See Ohnesorge (2007), p 232.

26 See also Merryman (1977); Snyder (1982).

27 See La Porta et al. (1997); La Porta et al. (1998).

28 See Djankov (2016) referring to 'the experience of centrally planned economies' and documenting 'the waste of entrepreneurial talent and resources as a result of overregulation'.

29 For a rather uncritical acceptance of this thesis see Easterly (2006), p 86: 'Systems that rely on case law have a positive-feedback loop between the law and the arrangements that economic actors need to facilitate markets. Case law countries thus wind up with a wider variety of formal institutions more supportive of prosperity-property rights, contract enforcement, rule of law, and even corporate accountability - than do civil-law countries'. But see Roe (2006) who argues that politics instead of legal origins is a more relevant causal factor.
} 
There have been criticisms of the 'law matters' thesis and 'legal origins' literature for what is seen to be a US-centred approach. ${ }^{30}$ Implicitly, the thesis seems to assume that US law is the the goal of legal convergence, the benchmark and the end of (legal) history. ${ }^{31}$ There are also criticisms on the basis that it is the work of a small group of elite financial economists with a limited knowledge of legal differences and whose cross-cultural legal comparisons display deficiencies. ${ }^{32}$ The civil/ common law distinction underlies the thesis with membership of a legal family seen as a prominent factor in past and present economic development. The way in which legal systems are assigned to one or other of the so-called legal families is however, crude. As an example, France is put in the same legal family as Lithuania although their economies and their laws are very different in many other respects. Legal systems are all mixed to a degree, and the civil law/common law divide appears especially irrelevant in relation to the economic laws addressed in the legal origins literature. ${ }^{33}$ Other aspects of a society, such as politics, culture or religion, and geographical position seem intuitively to be much more likely to influence economic development than membership of a particular legal family. ${ }^{34}$ Other distinctions such as EU/non-EU, Eastern/Western Europe, and Baltic/non-Baltic countries appear prima facie more relevant than a legal origins categorisation that had Latvia and Taiwan in one legal category with Lithuania and Syria in another. ${ }^{35}$

Notwithstanding these criticism, the legal origins literature has heavily influenced the DB Business reports with many of the leading lights in the legal origins movement shaping the commissioning and content of the Doing Business reports. ${ }^{36}$ One of these 'leading lights' Simeon Djankov, has stated ${ }^{37}$ :

The inspiration behind Doing Business was two-fold. First, both Shleifer and I had previously researched the experience of centrally planned economies and documented the waste of entrepreneurial talent and resources as a result of overregulation. With the collapse of communism, research on the benefits of simpler regulation would be of use to reformers in Eastern Europe. Second, in his book The Other Path, Hernando de Soto (1989) showed that the prohibi-

\footnotetext{
30 See generally Michaels (2009). There is also a symposium on the legal origins thesis in the 2009 Brigham Young University Law Review.

31 On the so-called end of history for corporate governance see Hansmann and Kraakman (2000). The title of this paper consciously and provocatively echoes Fukuyama (1992).

32 See Braendle (2006).

33 See generally on 'mixing' of legal systems Siems (2016).

34 See Acemoglu et al. (2001); Stulz and Williamson (2003); Licht et al. (2005).

35 See Siems (2007), p 65.

36 See the 2004 Doing Business report, p vii: 'Doing Business in 2004 was prepared by a team led by Simeon Djankov [...] Andrei Shleifer co-authored the main background studies and provided valuable suggestions throughout the writing of the report. Florencio Lopez-de-Silanes and Rafael La Porta coauthored the background studies on starting a business, hiring and firing workers, and enforcing a contract'.

37 Djankov (2016). See also p iv of the foreword to the 2017 Doing Business report.
} 
tively high cost of establishing a business in Peru denies economic opportunity to the poor. ${ }^{38}$

Indeed, the DB methodology has been subject to many of the same criticisms as the legal origins literature including a common law bias, a US-centric approach and an underlying deregulation and free market agenda. A World Bank Independent Review Panel has itself pointed out that the 'Doing Business project has, rightly or wrongly, been associated with a broad deregulation agenda'. 39

The fourth section of this paper reverts to criticisms of the DB project but first it is appropriate to consider its influence and esteem. ${ }^{40}$

\section{Doing Business-Influence and Esteem}

The Doing Business project is one of the most prominent knowledge products produced by the World Bank. ${ }^{41}$ It enjoys a high public profile with millions of hits on its website each year and has become a major resource for academics, journalists, and policymakers. This is not altogether surprising given the intellectual prestige and respectability of the World Bank. John Braithwaite and Peter Drahos ${ }^{42}$ have referred to the fact that certain models are adopted "when they appeal to identities that we hold dear. An identity that is particularly crucial in this regard is that of being successful, modern, civilised, advanced. The periphery models the centre in the world system because of this pursuit of modernity in identity (or postmodernity, for the truly avant-garde)'.

The authors of the DB reports have claimed considerable success in persuading countries to institute reforms consistent with their recommendations ${ }^{43}$ and leading economies across the world have hailed their own efforts to climb the DB rankings. The former UK Prime Minister, David Cameron, has said that Britain 'aim[s] to be number one in Europe and in the top five worldwide in the World Bank's Doing Business rankings by 2020 and to lead Europe in attracting foreign investment' ${ }^{44}$ When Narendra Modi was elected Prime Minister of India, he explicitly set out the target of achieving 50th place in the ranking as a benchmark for his administration. This would mean an improvement of almost 100 places compared to India's then

\footnotetext{
38 See also Djankov et al. (2002); Djankov et al. (2003); Botero et al. (2004).

39 Independent Doing Business Report Review Panel (2013), p 11.

40 See generally Davis (2012).

41 See generally Besley (2015).

42 Braithwaite and Drahos (2000), p 591.

43 See the statement at p v of the foreword to the 2018 Doing Business report: 'Over the past decade, more than 60 economies have established regulatory reform committees that use the Doing Business indicators. As a result, governments have reported more than 3180 regulatory reforms, including about 920 reforms that have been inspired by Doing Business. This is true impact'.

44 See http://www.contractoruk.com/news/0012003conservative_manifesto_key_pledges_contractor s.html.
} 
position. ${ }^{45}$ In 2012, Russian President Vladimir Putin suggested that Russia should get into the top 20 in the DB rankings by $2018 .^{46}$

Developing countries may be particularly receptive to ideas advanced by the World Bank because of the scale of its 'legal technical assistance' operations and donor countries may use the DB rankings in gauging whether a particular destination is safe for investment. Perhaps the most use of the DB rankings is made by the smaller developing countries as a way of trying to show foreign investors that they have improved their business environment.

Nevertheless, countries may have made 'strategic' use of the rankings by amending formal regulations in a way that has not much bearing with the substance or the reality on the ground. The case of Rwanda has been cited in this regard. It has moved up the rankings from a low of 158th in 2005 to a high of 41 st despite the fact that it is one of the world's poorest countries. It ranks higher in the countries than countries that have much higher average incomes. ${ }^{47}$ Clearly, one's position in the DB rankings is not a neat proxy for per capita GDP, whether on an absolute or purchasing power basis. ${ }^{48}$ This divergence is one of the factors spurring criticism of the DB rankings to which the paper now turns.

\section{Doing Business-Criticisms}

There has been substantial criticism of the DB report and rankings and these criticism fall under four main heads namely (1) an actual or perceived common law bias; (2) a preference for deregulation and free market solutions; (3) lack of correlation between the DB rankings and the empirical realities on the ground; (4) methodological flaws in the way in which the rankings are drawn up. The heads however, to a certain extent overlap.

The first DB report in 2004 did not hide its deregulation and free market perspectives as well as its preference for the common law over the civil law which, to a certain extent, was a hangover from the earlier legal origins' literature. The report

\footnotetext{
45 See generally Besley (2015), pp 99-100 and see http://profit.ndtv.com/news/economy/article-india-tomove-up-rapidly-in-ease-of-doing-business-ranking-arun-jaitley-1414337 It does not appear likely that the target will be achieved. India appears as 100th in the rankings in the 2018 Doing Business report (see p 4).

46 See https://in.rbth.com/opinion/2015/11/26/ease-of-doing-busines-rank-crucial-for-russia_544593/: 'When Russian authorities set a goal for increasing foreign investment in the country, they realized it was important to show investors there was a significant change in the business environment. The Doing Business ranking was selected as a benchmark'. Russia actually ranks as 35th in the 2018 Doing Business report ( $\mathrm{p} 4)$.

47 For a discussion see Besley (2015), p 117. On Rwanda's current ranking of 41st see 2018 Doing Business report, $\mathrm{p} 4$.

48 For league tables showing GDP growth in countries over the years see the World Bank and International Monetary Fund (IMF) databases, at https://data.worldbank.org/indicator/NY.GDP.MKTP.KD.ZG and http://www.imf.org/external/datamapper/NGDP_RPCH@WEO/OEMDC/ADVEC/WEOWORLD and for access to a large number of databases as well as visualization tools in connection with those databases see https://knoema.com and in particular https://knoema.com/atlas/ranks/Real-GDP-growth.
} 
argued that a 'heavy' regulatory regime brought about the worst results in terms of economic outcomes since it was usually associated with inefficiency within public institutions, long delays in reaching decisions, high costs of administrative formalities, lengthy judicial proceedings, higher unemployment and more corruption, less productivity, and lower investment. ${ }^{49}$ The report had the following message: 'Common law countries regulate the least. Countries in the French civil law tradition the most. However, heritage is not destiny,. ${ }^{50}$ The report contained the overall conclusion that 'one size can fit all' in respect of the legal regulation of business.

In the 2004 report France was ranked at 44th and there was some surprise and disappointment in France at this relatively low ranking; behind countries such as Jamaica and Botswana. French commentators and institutions severely criticized the 2004 report for what was alleged to be a faulty understanding of French law and legal culture. For example the Association of the Friends of French Legal Culture published two critical commentaries ${ }^{51}$ and a research institute was established to demonstrate the attractiveness of French law. ${ }^{52}$ It may be that the impact of these contributions in the international sphere was muted, if not largely nullified, however, by the fact that almost all of them were published in French. ${ }^{53}$ Nevertheless, the French criticisms appear to have borne some fruit. Professor Fauvarque-Cosson $^{54}$ has argued that the French reactions were constructive in that they forced the World Bank to revise some of its suppositions. For instance, the 'one size fits all' idea that was emphasised in the 2004 report $^{55}$ disappeared from subsequent reports. Moreover, France was motivated to modernise its law, and its mindset. The political and legal community in France immediately engaged in efforts to restore the reputation of French law in the area of economic efficiency and the position of France has improved in the rankings. ${ }^{56}$

The broader criticisms of the DB rankings have however, been taken up by others both inside and outside the World Bank. In 2008 an Independent Evaluation Group within the World Bank recommended greater transparency in the DB reports and some modifications to the DB methodology. ${ }^{57}$ It was also suggested that the focus on regulatory costs and burdens should only be one dimension of any overall reform of the investment climate in a particular country. These criticisms were amplified in

\footnotetext{
49 See the 2004 Doing Business report, p 83: 'Heavier regulation of business activities generally brings bad outcomes, while clearly defined and well-protected property rights enhance prosperity'.

502004 Doing Business report, p xiv.

51 See Association Henri Capitant des amis de la culture juridique Francaise (2006) and available on http://www.henricapitant.org/.

52 Fondation pour le droit continental-see http://www.fondation-droitcontinental.org/.

53 See the comment in Michaels (2009), p 772: 'Somewhat typically, almost all of these contributions were published in French, leaving them with almost no impact in the international sphere'. There are however Russian and Chinese translations on the Henri Capitant website but none in English!

54 See Fauvarque-Cosson and Kerhuel (2009); Ménard and du Marais (2008).

552004 Doing Business report, p xvi.

56 Its position in the 2018 rankings is 31 st-see 2018 Doing Business report, p 4 which also on pp 57-58 uses the example of French reforms in the area of resolving insolvency as a successful case study.

57 World Bank Independent Evaluation Group (2008).
} 
the 2013 report of the World Bank's own Independent Review Panel. ${ }^{58}$ This report argued that:

- the Doing Business report had the potential to be misinterpreted;

- the names of some of the specific indicators such as 'Getting credit' were misleading;

- it relied on a narrow information source;

- it only measured regulations applicable to categories of business that could be captured through its methodology;

- its data-collection methodology could be improved;

- it was not designed to help countries respond appropriately; and

- use of aggregate rankings was problematic.

The Review Panel expressed particular concerns about rankings because these involved a process of aggregation across topics including a value judgment about what was 'better' for doing business and how much better it was. In its words, 'aggregation relies on strong built-in assumptions, making it an inherently value laden practice. The act of ranking countries may appear devoid of value judgement, but it is, in reality, an arbitrary method of summarising vast amounts of complex information as a single number'. ${ }^{59}$

The Review Panel report also stressed the methodological imperfections in the DB rankings. ${ }^{60}$ This has been taken a stage further in a recent study which highlights substantial mismatches on the time estimates given in respect of certain DB indicators and what happens in practice in developing countries. ${ }^{61}$ In particular, it compares the figures in the World Bank DB study with those in Word Bank firm-level Enterprise surveys which focus more on how long it takes managers to comply with bureaucratic requirements in practice. ${ }^{62}$ In a comparison of three broadly comparable indicators from the DB and Enterprise surveys, the study finds that the estimate of the legally required time for firms to complete certain legal and regulatory processes measured in the DB rankings does not correlate even modestly well with the

\footnotetext{
58 Independent Doing Business Report Review Panel (2013), p 11.

59 Ibid., p 20. For a strong defence of aggregate rankings see a 2006 paper by the team behind the DB rankings - S. Djankov et al, 'Doing Business indicators: Why aggregate and how we do it'. The paper is highlighted prominently in the methodology section of the DB website-see http://www.doingbusiness. org/ /media/WBG/DoingBusiness/Documents/Methodology/Other/why-aggregate-doing-business-2006. pdf.

60 Independent Doing Business Report Review Panel (2013), pp 21-23: 'The report's methodology simplifies much of the qualitative diversity and nuance at work in different legal systems into a very basic, often confusing rendering of (apparently) quantifiable measurements that cannot credibly claim to reflect legal reality to any significant degree'.

61 See Hallward-Driemeier and Pritchett (2015).

62 Ibid., p 124: 'the Enterprise Surveys do not try to measure what should happen as a result of formal policies and regulations, but rather what did happen in practice. They gather responses from large, random samples of firms in the main urban centers in a country, using both questionnaires and interviews. Registered firms above a minimum size, generally 10 employees, are included, as well as foreign and state-owned enterprises [emphasis added]'.
} 
experience of firms in the Enterprise surveys. Moreover, in countries with repeated Enterprise surveys data, there is no strong association between changes in DB times and changes in actual times as reported in the Enterprise surveys. If anything, reductions in DB times are equated with higher reported actual times in the Enterprise surveys. ${ }^{63}$ The argument therefore, is that when strict legal regulation meets weak governmental capabilities for implementation and enforcement, regulations are best thought of not as creating 'rules' to be followed, but instead of creating a space in which 'deals' of various kinds are possible.

\section{Doing Business Criticisms-Response by the World Bank}

Notwithstanding the criticisms contained in the Independent Panel report, the World Bank is committed to keeping the DB report and rankings. This was made clear by World Bank President Jim Yong Kim, in his foreword to the 2015 report. ${ }^{64} \mathrm{He}$ referred to the many critiques by the Independent Panel but said that a decision was made to set a 2-year target to improve the DB methodology 'without damaging the overall integrity of this valuable publication'.

President Kim also highlighted some of the advantages of DB stating that its greatest strength was its transparency and conformity with clearly stated criteria. ${ }^{65}$ The DB project took the same set of hypothetical questions to different economies and collected the answers to these; this meticulous insistence on using the same standard everywhere gave the project remarkable comparability across economies. He acknowledged however, that the same strength was inevitably a source of some weaknesses in that, contrary to what some people believed, the DB project was not based on sample surveys of firms. Such surveys were simply not feasible and neither was it feasible to design a case study that served as an equally good fit for all economies given their different states of development. The report aimed to have a global coverage and therefore the choice of indicators was partly constrained by the data that could realistically be collected in economies in the least stage of development. ${ }^{66}$

The World Bank has acknowledged that macro-economic stability, the absence of corruption, competition law policies and workforce skills, are all important factors in building a foundation for sustainable economic development but are not measured by the DB indicators. ${ }^{67}$ Nevertheless, it has pointed out that economies that rank well on the DB scorecard also perform well on measures such as the Global

\footnotetext{
63 Ibid.

64 See $\mathrm{p}$ vii of the foreword to the 2015 Doing Business report.

65 See 2016 Doing Business report, p iv: 'Since the first Doing Business report was published [...] the team has implemented a number of methodological improvements, expanding the coverage of regulatory areas measured and enhancing the relevance and the depth of the indicators. While initially the report was focused largely on measuring efficiency and the costs of compliance with business regulations, over the past 2 years there has been a systematic effort to capture different dimensions of quality in most indicator sets'.

66 Ibid., p v.

67 See 2018 Doing Business report, p 13.
} 
Competitiveness Index and Transparency International's Corruption Perceptions Index. ${ }^{68}$ The Singapore-Indonesia comparison may be cited in this connection. Singapore and Indonesia are neighbouring countries and highly developed Singapore ranks as 8th best in the latest available Corruption Perceptions index whereas the comparable ranking for Indonesia, still largely a developing country, is 88th. ${ }^{69}$ Singapore ranks second in the 2018 DB rankings (and first in a number of previous Doing Business rankings) whereas the equivalent ranking for Indonesia is 91 st.

One might also argue that complex and inefficient laws, of the kind condemned in the DB reports and rankings, enhance opportunities for graft and corruption. More streamlined business regulations of the type advocated in the DB rankings reduce corruption possibilities in that businesses may no longer feel the need to bypass such regulations. Developing countries may have a myriad of rules but firms with the necessary finance, power or political connections find ways of getting around the red tape. In short, better rules improve enforcement. Evidence from the World Bank's enterprise survey programme can be used in support of the proposition that firms follow the rules when they are not too onerous but where the rules are complicated, this is fertile ground for corruption. ${ }^{70}$

Somewhat paradoxically, some of the most persuasive advocacy for retaining the DB reports and rankings in something like their present form, comes from a member of the Independent Review Panel, Professor Tim Besley. ${ }^{71}$ Besley argues that, even with all its imperfections, data collection of the kind undertaken in the DB project is part of the political economy of policymaking. ${ }^{72}$ The DB indicators were also updated on an annual basis meaning that policy reforms were soon reflected in the indicators. The DB project had employed a consistent methodology which enabled country-level performances to be tracked over time. The DB project was also upfront about its limitations. It was a living project seeking to learn from criticisms; including efforts to improve the methodology and when there were changes in the indicators, careful attempts were made to maintain comparability and to explain the changes. In Besley's view, this approach contrasted favourably with that of many other widely used international databases. ${ }^{73}$

\footnotetext{
68 See 2016 Doing Business report, p 4.

69 For the Corruption Perceptions index see http://www.transparency.org/cpi2015/.

70 See also the new World Bank Chief Economist, Paul Romer, in the foreword to the 2017 Doing Business report ( $\mathrm{p} \mathrm{v}$ ): 'Potential entrepreneurs are often discouraged from setting up businesses if the requirements to do so are overly burdensome. When this is the case entrepreneurs often resort to operating within the informal sector which has less protection for labor conditions and is more vulnerable to economic shocks'.

71 See generally Besley (2015).

72 See Besley (2015), at p 106 stating that 'the main achievement of the Doing Business project has been to shed light and create a more informed debate on a range of differences in laws and regulations across countries in areas where little was known on a systematic basis before the project began'.

73 Ibid., p 105.
} 
A group of leading economists and policy makers have also mounted a strong defence of the DB reports and methodology ${ }^{74}$ They acknowledge that DB measures the official rules and not actual practice and that divergence between what is 'on the books' and what happens in practice was always an issue. They suggested however, that rule-making was an important part of policy-making and affected institutional arrangements. In this context, an analogy was drawn with the Report of the Commission on the Measurement of Economic Performance and Social Progress, ${ }^{75}$ chaired by Joseph Stiglitz, which assessed the adequacy of Gross Domestic Product (GDP) as a measure of production in an economy. This Commission stated that 'the way in which statistical figures are reported or used may provide a distorted view of the trends of economic phenomena' but, at the same time it concluded that GDP was useful and that 'GDP is not wrong as such, but [may be] wrongly used. What is needed is a better understanding of the appropriate use of each measure. ${ }^{76}$ A similar line was proposed in relation to Doing Business.

The fundamental question is whether the approach taken by Doing Business is a step forward, not whether it measures everything or perfectly. In our view it represents a clear step forward, because it is informative about a number of important aspects of laws and regulations, it is useful as a benchmarking tool for policy-makers and because it exemplifies a method to cover a potentially large variety of rules and institutional arrangements. ${ }^{77}$

Despite these strong defences, it is submitted that the flaws in the DB reports and rankings cannot be glossed over so easily. The GDP analogy is an inappropriate one in that the GDP measure is much older and better established. It is at the cornerstone of economic policy-making throughout the globe. If it were abolished, then it would probably be necessary to replace it with something similar. ${ }^{78}$ One could hardly say the same about the DB rankings. They have only been around since 2004. While

\footnotetext{
${ }_{74}$ See 'A Review of Doing Business', available at http://www.doingbusiness.org/ /media/WBG/Doing Business/Documents/Methodology/Open-Letter-Review-of-the-Arguments-on-DB.pdf?la=en (accessed 20 July 2018). The open letter was published before publication of the Independent Review Panel report.

75 See Stiglitz, Sen and Fitoussi (2009).

${ }^{76}$ See the Executive Summary of the Stiglitz Commission report, in Stiglitz, Sen and Fitoussi (2009), p 8. GDP has been defined as 'the sum of gross value added by all resident producers in the economy plus any product taxes and minus any subsidies not included in the value of the products. It is calculated without making deductions for depreciation of fabricated assets or for depletion and degradation of natural resources—see https://knoema.com/atlas/ranks/Real-GDP-growth.

${ }^{77}$ See 'A Review of Doing Business', available at http://www.doingbusiness.org/ /media/WBG/Doing Business/Documents/Methodology/Open-Letter-Review-of-the-Arguments-on-DB.pdf?la=en (accessed 20 July 2018).

${ }^{78}$ It must be said however that the GDP measure can throw up some surprising statistical quirks and oddities. For instance, Libya tops the GDP growth figure for 2017 with growth of 55\% -annual percentage growth rate of GDP at market prices based on constant local currency - see particular https:// knoema.com/atlas/ranks/Real-GDP-growth. Ireland came top in 2015 with a growth rate of $25.5 \%$ and this unrealistically high figure for Ireland has been explained on the basis of 'a number of once-off factors, including the relocation of aircraft leasing assets, a spate of so-called corporate inversion deals and the transfer of international patents, all of which were widely recognised as not reflecting changes to the real economy'—see Irish Times 12 July 2016.
} 
they have their staunch advocates, they have also been severely criticised from the beginning. While they are important and influential, one can hardly say that they are at the core of policy making. Policy makers, politicians and the public hardly obsess about DB rankings in the same way as they do about GDP growth.

While the DB reports address important topics, they are weak on execution and technique. The reports have something of a missionary or proselytising tone; making the case on behalf of the DB indicators, and success in these indicators but without expressing appropriate scepticism and taking a balanced view of the evidence. There are many problems and technical flaws. ${ }^{79}$ This proposition becomes more apparent when one considers in detail how the 'Getting Credit' and 'Resolving Insolvency' indicators are drawn up. Firstly, the paper considers 'Getting Credit'.

\section{Doing Business-Getting Credit}

The first thing to point out is that this indicator is inappropriately named for, despite the name, this indicator does not really measure 'getting credit' at all. The World Bank Independent Review Panel pointed out that in reality it measured whether a country had a credit bureau system that collected and distributed fundamental information about credit and a secured transactions legal regime that allowed entrepreneurs access to credit using movable property. ${ }^{80}$ The indicator did not measure directly what it purported to address. ${ }^{81}$

The DB reports in their methodology section explain in detail how the 'Getting Credit' indicator is composed with the indicator including both 'legal rights' and 'sharing of credit information' features. ${ }^{82}$ The 'legal rights' feature purports to ascertain the extent to which certain elements are present within the secured credit/ secured transactions/collateral laws and the corporate insolvency (bankruptcy) laws of a particular country. A second aspect considers the coverage, scope and accessibility of credit information that is available through credit bureaus or credit registries. $60 \%$ of the overall ranking is made up of the 'legal rights' element and the remaining $40 \%$ is attributed to the 'sharing of credit information element'.

In determining a country's overall ranking, scores on the individual sub-indicators are aggregated with the higher scores signifying that the collateral and insolvency laws in a particular economy are, in the words of the World Bank, 'better designed to expand access to credit'. ${ }^{83}$ The 'Getting Credit' indicators has been a feature of the DB reports and rankings from the very beginning though there have been some changes to the list of sub-indicators and adjustments to the detailed methodology

\footnotetext{
${ }^{79}$ For earlier criticism of incorrect theoretical and methodological approaches in the DB project see Arruñada (2007).

${ }^{80}$ Independent Doing Business Report Review Panel (2013), p 15.

81 See generally McCormack (2015).

82 For some explanation of the methodology on 'getting credit' see the 2018 Doing Business report, pp 88-91 and two case studies in the 2017 Doing Business report, pp 52-64.

832018 Doing Business report, p 89. See also Lopez-de-Silanes (2008).
} 
over the years. ${ }^{84}$ One might argue that these changes provides evidence of learning from experience and demonstrates the project's capacity for self-development. This seems however, to be far too sanguine an assessment. It is submitted that the 'Getting Credit' indicator has three main imperfections-(1) glitches in methodology and related data inaccuracies; (2) unblinking alignment with a highly contestable model and (3) formalistic rule following.

\subsection{Glitches in Methodology and Related Data Inaccuracies}

Some of the scores on the individual sub-indicators seem questionable. The DB report explains that information on the legal rights of borrowers and lenders are gathered through a questionnaire provided to financial lawyers. ${ }^{85}$ The questionnaire responses are clarified and verified through several rounds of follow-up communications with respondents. This may take the form of teleconference calls or on-site visits. The data is also verified through contacts with third parties; by analysis of laws and regulations as well as public sources of information. The World Bank team may have to reconcile apparently divergent information from questionnaire responses and from publicly available data sources. In this respect, the DB project is not unusual but there is some lack of transparency in relation to the way in which the questionnaires are processed to arrive at a final score. For instance, the UK score is questionable in many instances ${ }^{86}$ and is, at best, a rough and ready classification which ignores a lot of individual nuances and differences. For instance, the score appears to relate only to England. Scotland has a separate legal system with a distinctive law on security rights ${ }^{87}$ but there is no indication that this aspect was taken into account in the DB score card. The DB project gives the UK a score of 7 out of a possible 12 on the legal rights indicator ${ }^{88}$ whereas taking the indicators at their face value, this commentator would give it an 8.5 or a 9 depending on how the questions are interpreted.

The answers given in the DB score card seem highly problematic in respect of one sub-indicator and plain wrong on another. For example, DB asks whether a modern collateral registry exists in which registrations, amendments, cancellations and searches can be performed online by any interested third party and for the UK a negative answer is given. There is an issue about what is meant by the expressions 'modern collateral registry' or 'interested third party' but the UK company charge registration system now allows details of security interests (charges) created by a company to be registered online by the corporate debtor or by the secured party. ${ }^{89}$

\footnotetext{
84 See generally on the underlying methodology Djankov et al. (2007).

85 See the 2018 Doing Business report, p 88.

86 The 2018 Doing Business report in respect of the UK can be found at http://www.doingbusiness.org/ data/exploreeconomies/united-kingdom.

87 On the position in Scotland see generally Steven (2013).

88 See http://www.doingbusiness.org/data/exploreeconomies/united-kingdom\#getting-credit/.

89 Companies Act 2006 (Amendment of Part 25) Regulations 2013 (SI 2013/600) which from April 6th 2013 amended Part 25 of the Companies Act 2006 concerning the registration of company charges. On the reforms see generally Graham (2014). But for the argument that further reforms are still needed see Raczynska and Gullifer (2016).
} 
Online searching is also permissible by any party who wishes to ascertain basic details of the charge. The security instrument itself is also available online and so the system is quite comprehensive in that respect. The system is however, confined to charges strictly so-called and does not cover any broader notion of security interest. ${ }^{90}$ Moreover, it is confined to charges created by companies and does not apply to similar security interests granted by individuals or non-incorporated entities. But it is still not clear why DB answers the question 'no' in the case of the UK. The system is 'modern' - being brought into existence in 2013 - and can be operated online. In the circumstances, it is suggested that the UK merits at least a half mark.

Some DB defenders may brush such criticisms aside on the basis that the DB data is incapable of capturing the complexities of the legal system or on the basis of a culture clash between economists and lawyers. Tim Besley, for example, has conceded that economists can sometimes rightly be accused of being too willing to accept stylized and simplified characterisations of reality for the purposes of analysis. In his view, the need for economic variables that can be expressed in a compact manner means that some short-cuts are inevitable. ${ }^{91}$ In response to this however, while short-cuts may be acceptable in certain circumstances, crude (and inaccurate) measurements are not.

\subsection{Apparently Unthinking Alignment with Certain Models}

The 'Getting Credit' indicators seem highly prescriptive and overly committed to a particular view of secured transactions law that may not be best for a particular economy. ${ }^{92}$ The DB reports suggest that a high score on the indicators is likely to enhance the availability of credit. They present general evidence to the effect that the ability to use assets as collateral is likely to have beneficial effects for the cost and availability of credit. ${ }^{93}$ This is certainly a generally accepted view. According to Armour et al.: 'Creditor rights matter for debt finance. This is the main message of the empirical studies [...]. Strengthening the taking and enforcement of secured credit increases borrowers' access to credit and reduces [...] their cost of borrowing, ${ }^{94}$ But the evidence does not go much further. In particular, there is no evidence to the effect that any one aspect of the law of secured credit considered desirable by the World Bank, whether alone or in combination, will necessarily have positive

\footnotetext{
90 What is now s. 859A(7) Companies Act 2006 states that a charge includes a mortgage but there is no statutory definition of a charge as such. In Re BCCI (No 8) [1998] AC 214 Lord Hoffmann said that a charge is a security interest created without any transfer of title or possession to the beneficiary. Slade $\mathrm{J}$ explained in Re Bond Worth Ltd [1980] Ch 228 at 250 the technical difference between a 'mortgage' and a 'charge' lies in the fact that a mortgage involves a conveyance of property subject to a right of redemption, whereas a charge conveys nothing and merely gives the charge holder certain rights over the property as security for the loan.

91 See generally Besley (2015), p 110.

92 For a 'Getting Credit: Legal Rights' case study see 2017 Doing Business report, pp 52-57.

93 For theoretical perspectives on this issue see generally Akerlof (1970); Stiglitz and Weiss (1981); Hart and Moore (1998); Haselmann et al. (2009).

94 Armour et al. (2015).
} 
impacts. The evidence is lacking. Absolute commitment to a DB 'getting credit' blueprint ignores history and tradition in individual economies. ${ }^{95}$ It also risks countries simply copying the DB indicators and making formalistic rules changes to their respective laws that either have little or no impact, or may be counter-productive, in practice. $^{96}$

The DB indicators are drawn largely from Model Laws and Guiding Principles produced by international organisations such as UNCITRAL- the United Nations Commission on International Trade Law-with its Model Law on Secured Transactions $^{97}$ and the World Bank itself with its 'Principles for Effective Insolvency and Creditor/Debtor Regimes' ${ }^{98}$ These Model Laws etc. have been inspired by Article 9 of the US Uniform Commercial Code. Despite the fact that in terms of basic design it is now more than 60 years old and has got progressively more complex with successive incarnations, Article 9 has often been held out as 'state of the art' by secured credit reformers worldwide. ${ }^{99}$ Certainly, it has proved durable in the largest economy in the world and it has been tried and tested in commercial practice and judicial interpretation. In terms of basic approach and philosophy, it is intended to facilitate access to credit by easy-to-comply-with rules for the creation of security interests and making these security interests effective against third parties. In addition, security may be taken against almost all kinds of assets. ${ }^{100}$

It seems that unless one has a secured credit law that is modelled upon Article 9 then one will not do very well on the DB 'Getting Credit' indicator. ${ }^{101}$ New Zealand $^{102}$ and Australia ${ }^{103}$ both have such laws ${ }^{104}$ and along with the US rank in the top 10 on 'Getting Credit' with New Zealand being no 1 and the US itself ranked joint 2nd. Nevertheless, some of the choices in Article 9 (and the DB indicators) are contentious on a technical and, more generally, on a policy level. For instance, the DB indicators call for secured creditors to be given priority over employee claims and claims for unpaid taxes, both inside and outside formal liquidation procedures.

\footnotetext{
95 Despite the well established and well functioning credit markets in these countries, in the past, the Doing Business reports have rebuked (albeit obliquely) German and Austrian law for not having a comprehensive system for the registration of security interests over personal property-see World Bank, Doing Business reports for 2005 and 2004 at pp 47 and 68, respectively. The 2005 report suggests a simple solution to the problems afflicting personal property security law-the validation of universal charges and the creation of a unified registry of movable property charges indexed by the name of the debtor.

96 For an account of how China has made a great leap forward economically without necessarily adhering to World Bank blueprints see Kennedy (2013).

97 See http://www.uncitral.org/pdf/english/texts/security/ML_ST_E_ebook.pdf and for background see Foex and Bazinas (2007).

98 Revised in 2015 and available at http://pubdocs.worldbank.org/en/919511468425523509/ICR-Princ iples-Insolvency-Creditor-Debtor-Regimes-2016.pdf (accessed 20 July 2018).

99 See generally McCormack (2013).

100 See generally Winship (2016).

101 On possible reforms in England along US Art. 9 lines see Law Commission, Company Security Interests (Law Com No 295, 2005) and see generally Beale (2006); McCormack (2010).

102 Personal Property Securities Act 1999.

103 Personal Property Securities Act 2009; Barns-Graham and Gullifer (2010); Duggan (2011). For a review of the Act see Whittaker (2015).

104 See generally Beale et al. (2012), chapter 23; Sheehan (2011), pp 313-317.
} 
Some countries may consider this state of affairs to be undesirable on grounds of social solidarity or general public policy. ${ }^{105}$

On the more technical plane, the DB indicators along with Article 9 manifest a commitment to a notice filing system extending to functional equivalents of security interests such as financial leasing and transfers of receivables. In terms of the DB scorecard, major economies such as Germany and the UK are marked down because they do not follow this blueprint. Germany has essentially a registration-less regime of personal property security ${ }^{106}$ while the UK machinery for the registration of corporate security interests does not extend to legal instruments that have many of the same economic functions but which are legally distinct. There is no evidence that such aspects of the current German and UK systems have had deleterious consequences for the availability of credit. Financial lawyers in the City of London have indeed pressed for the retention of the UK system notwithstanding calls for reform along US Article 9 lines. ${ }^{107}$ What works best for the UK in terms of 'dirty' empirical reality may not be a straight-down-the-line adherence to DB prescriptions. This leads on a third criticism that DB indicators encourage formalistic rule following that pays little heed to the multifaceted complexities of particular countries.

\subsection{Formalistic Rule Following}

While developed 'First World' countries fill many of the places in the top 10th and top 20th of the DB 'Getting Credit' rankings, there are some surprise inclusions. Speaking of an earlier DB report, a lead economic analyst with the charity CAFOD, said: 'Decision makers will rightly wonder how much weight to give to a publication that has ranked Zambia 12th in the world on access to credit for businesses, when over $90 \%$ of small businesses there cite this as a major constraint for their success'. ${ }^{108}$ Zambia has since improved in the rankings to joint 2 nd in the latest (2018) iteration and this begs the question of how some 'developing' countries where credit availability is seen to be a problem in practice score so highly on 'Getting Credit'? For instance, apart from Zambia, and despite the recent history of violence and political instability in these countries, Colombia and Rwanda rank highly whereas Japan is ranked 77th, France 90th and the Netherlands 105th. How can this be?

A simple response would be to say that it is all explained by the methodology and possibly by the fact that the name of the 'Getting Credit' is misleading with an unwary consumer of the data presuming that it refers to actual measures of credit. Instead, the indicator is based on legal aspects of collateral and bankruptcy laws and also on the sharing of credit information. It is certainly not a measure of the quantity or allocation of credit and many aspects of the environment in which credit

\footnotetext{
105 For arguments however, in favour of the 'full' priority of secured claims see Armour (2006); Armour (2008).

106 See generally Brinkmann (2016); Hausmann (1996).

107 See generally Calnan (2010) and see also Goode (2001); Bridge (2006).

108 See International Trade Union Confederation (2013).
} 
is obtained are not considered such as the competitiveness of the financial system or aspects of financial regulation.

One could rename the indicator something like 'Legal aspects of collateral and credit information' but such a title would not have the instant, attention-grabbing appeal of 'Getting Credit' which is presumably the reason why the indicator is named in the way that it is. The message to countries appears essentially to be that the way to get up the rankings is to reform your laws along the lines of the indicators without necessarily considering what reforms might take root in practice or which happen to conform to the legal history and traditions of that country. Certainly, the DB reports hail certain countries as 'best reformers' and Rwanda ${ }^{109}$ and Colombia $^{110}$ have been singled out for praise in this respect. The 2016 DB report says:

Rwanda began strengthening its secured transactions system in 2009, when it introduced provisions allowing a wider range of assets to be used as collateral, permitting a general description of debts and obligations in a security agreement, allowing out-of-court enforcement of collateral and granting secured creditors absolute priority within bankruptcy. It also created a new collateral registry. More recently, in 2013 Rwanda provided greater flexibility on the types of debts and obligations that can be secured through a collateral agreement. $^{111}$

Colombia is said to have made the biggest improvement in Latin America over the past 12 years with reforms most notably in the areas of paying taxes and getting credit. The 2016 DB report states:

Colombia improved access to credit last year by adopting a new secured transactions law that takes a functional approach to secured transactions and by establishing a centralized, notice-based collateral registry. The law broadens the range of assets that can be used as collateral, allows a general description of assets granted as collateral, establishes clear priority rules inside bankruptcy for secured creditors, sets out grounds for relief from a stay of enforcement actions by secured creditors during reorganization procedures and allows out-of-court enforcement of collateral. ${ }^{112}$

Rwanda and Colombia may well have made all these changes to the 'law on the books' but what evidence is there that it has enhanced credit availability in practice or even that the reforms have taken root and work well with other parts of the legal system? The underlying message from DB seems to be that global competition is a strong enough force to bring about change in the laws and that it is possible for a country to amend its existing legal norms to any degree that is desired or, in other words, that legal systems are relatively free to choose from an open-ended menu of legal rules. The proposition however, does not pay much, if any, regard to the

\footnotetext{
$\overline{109}$ See http://www.doingbusiness.org/reforms/overview/economy/rwanda.

${ }^{110}$ See http://www.doingbusiness.org/reforms/overview/economy/colombia.

111 At p 16.

112 Ibid. See also the 2017 Doing Business report, p 55.
} 
rich literature on legal 'transplants' ${ }^{113}$ and their effectiveness or otherwise. ${ }^{114}$ This literature highlights the role of existing legal norms in shaping subsequent legal developments. $^{115}$

There is also empirical evidence to the effect that laws, to be effective, need to have local constituencies with a strong interest in the understanding and application of the laws. It has been suggested that the interdependence of legal rules means that there are only a few rules that can be understood and applied without reference to other legal rules or concepts. ${ }^{116}$ Reforms directed from outside may distort rather than improve the domestic legal framework unless there are complementarities between the new law and pre-existing legal institutions. The idea that law is a cognitive institution means that to be effective and actually change behaviour, law must be understood and embraced by those using the law, i.e. 'customers' and legal intermediaries. Legal change emanating from an external source, while it might precipitate more radical nominal change, insulates the law-making process from local political and socio-economic development and creates distance between it and the phenomenon of continuous adaptation and innovation. ${ }^{117}$

There is a need to draw a distinction between factors that may suggest the need for changes in the law and the form in which the law absorbs the need for change. One commentator remarks ${ }^{118}$ that 'the first instinct of lawyers, which is simply to transplant world-class legal institutions to developing countries, will most likely produce little more than a harvest of dead leaves. The institutions important to development are more likely to bear fruit if they evolve out of roots already growing in the soil of particular countries'. The results of the reform process have historically been shaped by legal doctrine and legal doctrine tends to cause the law to develop in a pathdependent fashion. Legal doctrine is an independent factor that shapes the form of future development. ${ }^{119}$ Change may be effected by adapting existing legal concepts rather than by introducing new ones since existing concepts are most developed and therefore safest to use. Legal concepts behave differently in different countries and the importation of a concept may have unintended consequences for the rest of the body of law in the recipient country. ${ }^{120}$

In an analysis and evaluation of reforms in Eastern European, Berkowitz, Pistor and Richard ${ }^{121}$ show various potential inefficiencies when law is transplanted into an 'alien' implementing or enforcing environment. In their analysis, indigenous law making operates as a kind of focal point for cooperative law-making behaviour which then serves as the focal point for cooperative economic behaviour. They share

\footnotetext{
113 The classic work here is Watson (1974); and for a retrospective assessment see Cairns (2013).

114 See generally on the 'political' dimensions of transplants Kahn Freund (1974); Bebchuk and Roe (1999).

115 Twining (2004); Twining (2005); Spamann (2009); Cabrelli and Siems (2015).

116 Pistor (2002).

117 See also Waelde and Gunderson (1994); DeLisle (1999).

118 See Dam (2013), p 6.

119 See generally Armour et al. (2009).

120 See Teubner (1998).

121 See Berkowitz et al. (2003).
} 
some of the assumptions of the DB project that institutions are necessary for economic development but, in their analysis, 'local' institutions function better than transplanted ones. Therefore, attempts should be made to generate an internal process of legal development with a self-sustaining demand for legal innovation and change. The possibility of borrowing from other countries is not necessarily precluded but a good fit of foreign with domestic law will be enhanced by meaningful adaptation of imported laws to local conditions.

\section{Doing Business-Resolving Insolvency}

The Doing Business methodology section sets out how the 'resolving insolvency' rankings, are determined with two factors of equal weighting being taken into account. ${ }^{122}$ The first factor is the estimated recovery rate in insolvency proceedings with the second factor being the perceived strength of the insolvency framework in a particular country. The process of data collection follows broadly the same lines as that indicated for the 'Getting Credit' indicator with information for the assessments coming from questionnaire responses by local lawyers and insolvency practitioners and then verified through studying the relevant laws and regulations and other publicly available information on insolvency systems.

The methodology behind both factors that are used to determine the 'resolving insolvency' rankings seem highly contestable. The first part of the rankings depends on a set of standardised assumptions - the recovery rate is seen as a function of the outcome, time and cost of insolvency proceedings in respect of a particular kind of local company. ${ }^{123}$ No attempt to measure whether this type of company is typical of the particular economy or whether different outcomes and returns could be expected in relation to different types of company. The recovery rate is based on the percentage recovery by secured creditors through restructuring, liquidation or debt enforcement proceedings.

Calculation of the 'recovery' rate depends essentially on the subjective views of questionnaire respondents on the returns to creditors in their particular countries since in most countries, there will not be any publicly available and accurate data on these matters. Moreover, the focus in the rankings is solely on returns to secured creditors and if the insolvency law in a particular country had redistributionist elements this would necessarily reduce the returns to secured creditors and therefore a country's position in the rankings would fall. For example, recital 22 of the preamble to the recast EU Insolvency Regulation ${ }^{124}$ refers to improving the preferential rights of employees in the next review of the Regulation. This may have the effect of

\footnotetext{
122 For some explanation of the methodology on 'resolving insolvency' see the Word Bank 2018 Doing Business report, pp 111-115.

123 For the intellectual basis of the underlying methodology see Djankov et al. (2008).

124 Regulation (EU) 2015/848 of the European Parliament and of the Council of 20 May 2015 on insolvency proceedings (recast) [2015] OJ L 141/19-72.
} 
worsening the position of EU countries in the rankings depending on which, if any, policy option is adopted. ${ }^{125}$

The second aspect of the rankings attempt to measure the strength of the insolvency framework in a particular country and consists of the sum of the scores on a commencement of proceedings index, management of debtor's assets index, restructuring proceedings index and creditors' rights index. Scores on the index range from 0-16, with the higher scores supposed to signify that particular insolvency laws are better designed for rehabilitating viable firms and liquidating nonviable ones. This factor is premised on a cluster of normative assumptions that some elements of insolvency law are better or more desirable than others.

The insolvency framework assessment however, is relatively crude and depends largely on blunt 'all or nothing' measures assuming that particular legislative solutions are superior to others and missing out subtlety and nuances in the laws of a particular country. For example, under the rankings it is considered desirable that undervalue pre-insolvency transactions should be avoidable in the insolvency proceedings but the rankings do not make any attempt to assess whether avoidance proceedings are easy to achieve as a matter of practice or whether as a result of particular conditions it is very difficult to mount a successful avoidance action in a particular case. The 'approach simply asks whether one specific rule does or does not exist in different countries. This effectively disregards other legal solutions that achieve the same goal'. ${ }^{126}$

Another example of the relatively crude assessment is in relation to post-commencement financing i.e. financing of the debtor after the commencement of formal insolvency proceedings. Such financing is often seen as necessary to resolve 'debt overhang', i.e. existing assets being fully secured, and to cure 'underinvestment' problems, i.e. lack of incentives to finance value-generating projects. ${ }^{127}$ Such financing may be possible as a matter of practice in a particular country but there are no specific provisions of the law that authorise such financing. In these circumstances, it seems likely that the country would a zero mark, although, as matter of practice, post-commencement financing may be more readily available than in a country where there is specific legislative framework but there are so many restrictions that it is very difficult to access in reality. For instance, the UK lacks a fully set out new financing framework along the lines of section 365 of the US Bankruptcy Code and the UK government in $2009^{128}$ and 2016 sought views from stakeholders on the merits of introducing such a framework. On both occasions, the response was firmly in the negative. In 2016

[s]everal respondents commented to the effect that a lack of rescue finance rarely prevents business rescue, and that as long as a business is truly viable, there is no shortage of funding available. The existing framework does permit

\footnotetext{
125 See the statement by one of drafters of the European Insolvency Regulation, Balz (1996), p 509.

${ }^{126}$ Independent Doing Business Report Review Panel (2013), p 23. This comment is made by the Review Panel generally about the Doing Business approach.

${ }^{127}$ See generally Triantis (1993); Dahiya et al. (2003); McCormack (2007).

${ }^{128}$ See UK Insolvency Service (2009).
} 
rescue finance, and there is currently a market for rescue financing. [Some] respondents were concerned that any changes made to the order of priority would have a negative impact on the lending environment by increasing the cost of borrowing. ${ }^{129}$

\section{Doing Business-Conclusion}

Supporters of the World Bank Doing Business project argue that the DB rankings play a vital role in informing policy debate on the "critical matters of institutional reform underpinning growth and poverty reduction. The indicators also promote economic inclusion: success on the basis of rules, not connections (or corruption). ${ }^{130}$

On the other hand, countries who seek to improve their DB rankings may make formal changes to their laws with limited substantive effects. Law also behaves differently in different contexts and legal changes may not have the effects they have in the 'host' country when transplanted into a different implementing environment. The DB project appears to ignore the rich literature on legal transplants and the practical insights gained from decades of experience in law and development work. The DB project has a universalist, quasi-imperialist vision in that it puts legal rules and legal systems at the fulcrum of the development equation but a variety of non-legal factors clearly impact on a country's economic performance. While these factors may be difficult to quantify and measure scientifically, the same is also true of legal factors. Given the interaction between the different factors, the best we can hope for in terms of law and development theory is probably a pragmatic multifaceted set of indicators structuring and guiding inquiries rather than a bold and all-encompassing vision. In this connection, one might refer to the notion of reflexive law thereby acknowledging that the influence exerted by the export of legal norms is most likely to be effective when it seeks to achieve its ends not by direct prescription but by inducing second order effects on the part of social actors in the receiving State. ${ }^{131}$

Legal systems perform a number of different functions and there are choices, or a set of choices, to be made between means and ends. The relationship between means and ends is also contingent and uncertain. The DB project appears to embody a topdown formalistic logic assuming that if certain reforms are enacted the intended consequences will more or less automatically follow. Assessing 'success' also becomes a self-referential process which is judged in terms of how the legal system is changed instead of on how social realities have been affected. The DB project has a formalist tendency that appears to overestimate the closeness of the link between legal rules and structures and economic outputs in the 'real' world.

\footnotetext{
129 See UK Insolvency Service (2016b), para. 5.52.

130 See 'A Review of Doing Business', available at http://www.doingbusiness.org/ /media/WBG/Doing Business/Documents/Methodology/Open-Letter-Review-of-the-Arguments-on-DB.pdf?la=en (accessed 20 July 2018), p 2.

131 See generally Teubner (1983).
} 
The detailed engagement with the 'Getting Credit' and 'Resolving Insolvency' in this paper seeks to show the advantages of providing options that are based upon experience rather than setting out answers. The question becomes not whether legal rules have been transplanted from one country to another but whether the legal institutions in a particular country as a whole function in such a way as to support rather than to obstruct economic growth. Addressing this question calls more for a process of continuous adjustment and learning from experience rather than a simple 'big bang' solution which the Doing Business set of indicators appears implicitly to endorse. While this paper has highlighted flaws in some of the methodological implications underlying the process of data collection as well as possible inaccuracies, nevertheless the DB project remains a very valuable repository of statistical information and law and development assumptions. This repository may be quarried in the course of policy formation in particular countries and for purposes of comparative political economy. But the DB project should be stripped of its preoccupation with rankings - the process of simplifying complex matters of policy execution and design into a simple, single ranking. Such reductionism pays scant regard to subtlety and nuance disrespecting the reality that various functions might be carried out under the framework of a legal rule in one country but through an extra-legal procedure in another country. ${ }^{132}$ Context and cultural sensitivity are all important in the 'real' world and reducing all sorts of complicated matters to a single ranking hardly seems compatible with bringing about genuine improvements in the legal architecture for doing business.

Acknowledgements The author would like to thank the UK Economic and Social Research Council (ESRC) Global Challenges Research Fund for funding some of the research on which this article was based. I would also like to thank colleagues including Jingchen Zhao and Zinian Zhang and in particular Dr. Chuyi Wei for their work on the project.

Open Access This article is distributed under the terms of the Creative Commons Attribution 4.0 International License (http://creativecommons.org/licenses/by/4.0/), which permits unrestricted use, distribution, and reproduction in any medium, provided you give appropriate credit to the original author(s) and the source, provide a link to the Creative Commons license, and indicate if changes were made.

\section{References}

Acemoglu D, Johnson S, Robinson J (2001) The colonial origins of comparative development: an empirical investigation. Am Econ Rev 91:1369-1401

Akerlof GA (1970) The market for 'lemons': quality uncertainty and the market mechanism. Q J Econ $84: 488-500$

Armour J (2006) Should we redistribute in insolvency? In: Getzler J, Payne J (eds) Company charges: spectrum and beyond. Oxford University Press, Oxford

Armour J (2008) The law and economics debate about secured lending: lessons for European lawmaking? Eur Co Financ Law Rev 5:3-29

Armour J, Deakin S, Lele P, Siems MM (2009) How do legal rules evolve? Evidence from a cross-country comparison of shareholder, creditor, and worker protection. Am J Comp Law 57:579-629

132 Independent Doing Business Report Review Panel (2013), p 23. 
Armour J, Menezes A, Uttamchandani M, van Zwieten K (2015) How do creditor rights matter for debt finance? A review of empirical evidence. In: Dahan F (ed) Research handbook on secured financing in commercial transactions. Edward Elgar, Cheltenham (chapter 1)

Arruñada B (2007) Pitfalls to avoid when measuring institutions: is Doing Business damaging business? J Comp Econ 35:729-747

Association Henri Capitant des amis de la culture juridique Française (2006) Les droits de tradition civiliste en question. A propos des rapports Doing Business. Societé de Législation Comparée, Paris

Bakvis P (2009) The World Bank's Doing Business report: a last fling for the Washington consensus? Eur Rev Labour Res 15:419-438

Balz M (1996) The European Union Convention on insolvency proceedings. Am Bankruptcy Law J 70:485-531

Barns-Graham V, Gullifer L (2010) The Australian PPS reforms: what will the new system look like? Law Financ Mark Rev 4:394-404

Beale H (2006) The exportability of North American chattel security regimes: the fate of the English Law Commission's proposals. Can Bus Law J 43:178-199

Beale H, Bridge M, Gullifer L, Lomnicka E (2012) The law of security and title-based financing, 2nd edn. Oxford University Press, Oxford

Bebchuk L, Roe MJ (1999) A theory of path dependence in corporate ownership and governance. Stanf Law Rev 52:127-170

Benjamin P, Theron J (2009) Costing, comparing and competing: the World Bank's Doing Business survey and the bench-marking of labour regulation. In: Corder H, Bleazard J, Glazewski J (eds) Global administrative law: development and innovation. Juta, Cape Town, pp 204-234

Berkowitz D, Pistor K, Richard JF (2003) Economic development, legality, and the transplant effect. Eur Econ Rev 47:165-195

Besley T (2015) Law, regulation, and the business climate: the nature and influence of the World Bank Doing Business project. J Econ Perspect 29:99-120

Botero JC, Djankov S, La Porta R et al (2004) The regulation of labor. Quart J Econ 119:1339-1382

Braendle UC (2006) Shareholder protection in the USA and Germany: 'Law and Finance' Revisited. Ger Law J 7:257-278

Braithwaite J, Drahos P (2000) Global business regulation. Cambridge University Press, Cambridge

Bridge MG (2006) The Law Commission's proposals for the reform of corporate security interests. In: Getzler J, Payne J (eds) Company charges: spectrum and beyond. Oxford University Press, Oxford, pp 267-290

Brinkmann M (2016) The peculiar approach of German law in the field of secured transactions and why it has worked (so far). In: Gullifer L, Akseli O (eds) Secured transactions law reform: principles, policies and practice. Hart Publishing, Oxford (chapter 15)

Cabrelli D, Siems MM (2015) Convergence, legal origins, and transplants in comparative corporate law: a case-based and quantitative analysis. Am J Comp Law 63:109-154

Cairns JW (2013) Watson, Walton, and the history of legal transplants. Ga J Int Comp Law 41:637-696

Calnan R (2010) What is wrong with the law of security. In: De Lacy J (ed) The reform of personal property security law in the UK: comparative perspectives. Routledge-Cavendish, London, pp 162-187

Cohen AJ (2009) Thinking with culture in law and development. Buffalo Law Rev 57:511-586

Dahiya S, John K, Puri M, Ramírez G (2003) Debtor-in-possession financing and bankruptcy resolution: empirical evidence. J Financ Econ 69:259-280

Dam KW (2013) The law-growth nexus: the rule of law and economic development. Brookings Institution Press, Washington, DC

Davis K (2012) Governance by indicators: global power through classification and rankings. Oxford University Press, Oxford

Davis KE, Kruse MB (2007) Taking the measure of law: the case of the doing business project. Law Soc Inquiry 32:1095-1119

Deakin S, Lele P, Siems MM (2007) The evolution of labour law: calibrating and comparing regulatory regimes. Int Labour Rev 146:133-162

DeLisle J (1999) Lex Americana: United States legal assistance, American legal models, and legal change in the post-communist world and beyond. Univ Pa J Int Econ Law 20:179-308

Djankov S (2016) The Doing Business project: how it started: correspondence. J Econ Perspect 30:247-248

Djankov S, La Porta R, Lopez-de-Silanes F, Shleifer A (2002) The regulation of entry. Q J Econ 117:1-37

Djankov S, La Porta R, Lopez-de-Silanes F, Shleifer A (2003) Courts. Q J Econ 118:453-517 
Djankov S, McLiesh C, Klein MU (2004) Doing business in 2004: understanding regulation. World Bank publications, Washington, DC

Djankov S, McLiesh C, Shleifer A (2007) Private credit in 129 countries. J Financ Econ 84:299-329

Djankov S, Hart O, McLiesh C, Shleifer A (2008) Debt enforcement around the world. J Polit Econ 116:1105-1149

Duggan A (2011) A PPSA registration primer. Melb Univ Law Rev 35:865-904

Easterly W (2006) The white man's burden: why the West's efforts to aid the rest have done so much ill and so little good. Oxford University Press, New York

Fauvarque-Cosson B, Kerhuel A-J (2009) Is law an economic contest? French reactions to the doing business World Bank reports and economic analysis of the law. Am J Comp Law 57:811-829

Foex B, Bazinas S (2007) Reforming secured transactions: the UNCITRAL legislative guide as an inspiration. Schulthess, Geneva

Fukuyama F (1992) The end of history and the last man. The Free Press, New York

Goode RM (2001) Insularity or leadership? The role of the United Kingdom in the harmonisation of commercial law. Int Comp Law Q 50:751-765

Goodhart CA (1997) Economics and the law: too much one-way traffic? Mod Law Rev 60:1-22

Graham P (2014) Registration of company charges. J Bus Law 175-193

Hallward-Driemeier M, Pritchett L (2015) How business is done in the developing world: deals versus rules. J Econ Perspect 29:121-140

Hansmann H, Kraakman R (2000) The end of history for corporate law. Georget Law Journal 89:439-468

Hart O, Moore J (1998) Default and renegotiation: a dynamic model of debt. Q J Econ 113:1-41

Haselmann R, Pistor K, Vig V (2009) How law affects lending. Rev Financ Stud 23:549-580

Hausmann J (1996) The value of public-notice filing under Uniform Commercial Code Article 9: a comparison with the German legal system of securities in personal property. Ga J Int Comp Law 25:427-478

Independent Doing Business Report Review Panel (2013) Independent panel review of the Doing Business report. June 2013. World Bank, Washington DC. http://pubdocs.worldbank.org/ en/237121516384849082/doing-business-review-panel-report-June-2013.pdf. Accessed 20 Jul 2018

International Trade Union Confederation (2013) Why the World Bank must do better at Doing Business. http://www.ituc-csi.org/why-the-world-bank-must-do-better?lang=en/. Accessed $20 \mathrm{Jul}$ 2018

Kahn Freund O (1974) On uses and misuses of comparative law. Mod Law Rev 37:1-27

Kennedy D (2006) The 'rule of law', political choices, and development common sense. In: Trubek DM, Santos A (eds) The new law and economic development: a critical appraisal. Cambridge University Press, New York, pp 95-173

Kennedy D (2013) Law and development economics: toward a new alliance. In: Kennedy D, Stiglitz JE (eds) Law and economics with Chinese characteristics. Oxford University Press, New York, pp $19-70$

La Porta R, Lopez-de-Silanes F, Shleifer A, Vishny RW (1997) Legal determinants of external finance. J Financ 52:1131-1150

La Porta R, Lopez-de-Silanes F, Shleifer A, Vishny RW (1998) Law and finance. J Polit Econ 106:1113-1155

La Porta R, Lopez-de-Silanes F, Shleifer A (2008) The economic consequences of legal origins. J Econ Lit 46:285-332

Lee S, McCann D, Torm N (2008) The World Bank's 'employing workers' index: findings and critiques-a review of recent evidence. Int Labour Rev 147:416-432

Licht AN, Goldschmidt C, Schwartz SH (2005) Culture, law, and corporate governance. Int Rev Law Econ 25:229-255

Lin L, Ewing-Chow M (2016) The Doing Business index on minority investor protection: the case of Singapore. Singap J Legal Stud 46-69

Lopez-de-Silanes F (2008) Turning the key to credit: credit access and credit institutions. In: Dahan F, Simpson J (eds) Secured transactions reform and access to credit. Edward Elgar Publishing, Cheltenham (chapter 1)

McCormack G (2007) Super-priority new financing and corporate rescue. J Bus Law 701-732 
McCormack G (2010) Pressured by the paradigm - the Law Commission and company security interests. In: De Lacy J (ed) The reform of personal property security law in the UK: comparative perspectives. Routledge-Cavendish, London, pp 83-116

McCormack G (2013) Secured transactions law reform, UNCITRAL and the export of foreign legal models. In: Akseli NO (ed) Availability of credit and secured transactions in a time of crisis. Cambridge University Press, Cambridge, pp 33-60

McCormack G (2015) World Bank Doing Business project: should insolvency lawyers take it seriously? Insolv Intell 28:119

Ménard C, du Marais B (2008) Can we rank legal systems according to their economic efficiency? Wash Univ J Law Policy 26:55-80

Merryman JH (1977) Comparative law and social change: on the origins, style, decline \& revival of the law and development movement. Am J Comp Law 25:457-491

Michaels R (2009) Comparative law by numbers? Legal origins thesis, Doing Business reports, and the silence of traditional comparative law. Am J Comp Law 57:765-795

North DC (1990) Institutions, institutional change and economic performance. Cambridge University Press, Cambridge

Ohnesorge JK (2007) Developing development theory: law and development orthodoxies and the Northeast Asian experience. Univ Pa J Int Econ Law 28:219-308

Pistor K (2002) The standardization of law and its effect on developing economies. Am J Comp Law 50:97-130

Posner RA (1998) Creating a legal framework for economic development. World Bank Res Obs 13:1-11

Raczynska ME, Gullifer L (2016) The English law of personal property security: under-reformed? In: Gullifer L, Akseli O (eds) Secured transactions law reform: principles, policies and practice. Hart Publishing, Oxford (chapter 12)

Roe MJ (2006) Legal origins and modern stock markets. Harv Law Rev 120:460-527

Sarfaty GA (2009) Why culture matters in international institutions: the marginality of human rights at the World Bank. Am J Int Law 103:647-683

Sheehan D (2011) The principles of personal property law. Hart Publishing, Oxford

Siems MM (2007) Legal origins: reconciling law \& finance and comparative law. McGill Law J $52: 55-81$

Siems MM (2016) Varieties of legal systems: towards a new global taxonomy. J Inst Econ 12:579-602

Snyder FG (1982) The failure of law and development. Wis Law Rev 373-396

Spamann H (2009) Contemporary legal transplants: legal families and the diffusion of (corporate) law. Brigh Young Univ Law Rev 1813-1878

Steven A (2013) Secured transactions reform. Edinb Law Rev 17:251-256

Stiglitz JE, Weiss A (1981) Credit rationing in markets with imperfect information. Am Econ Rev 71:393-410

Stiglitz JE, Sen A, Fitoussi J-P (2009) Report of the commission on the measurement of economic performance and social progress. https:/www.insee.fr/en/statistiques/fichier/2662494/stiglitzrapport-anglais.pdf. Accessed 20 Jul 2018

Stulz RM, Williamson R (2003) Culture, openness, and finance. J Financ Econ 70:313-349

Teubner G (1983) Substantive and reflexive elements in modern law. Law Soc Rev 17:239-285

Teubner G (1998) Legal irritants: good faith in British law or how unifying law ends up in new divergences. Mod Law Rev 61:11-32

Triantis GG (1993) A theory of the regulation of debtor-in-possession financing. Vanderbilt Law Rev 46:901-935

Trubek DM (2006) The 'rule of law' in development assistance: past, present, and future. In: Trubek DM, Santos A (eds) The new law and economic development: a critical appraisal. Cambridge University Press, New York, pp 74-94

Trubek DM, Galanter M (1974) Scholars in self-estrangement: some reflections on the crisis in law and development studies in the United States. Wis Law Rev 1062-1102

Twining W (2004) Diffusion of law: a global perspective. J Legal Plur 36:1-45

Twining W (2005) Social science and diffusion of law. J Law Soc 32:203-240

UK Insolvency Service (2009) Encouraging company rescue: a consultation. http://webarchive.natio nalarchives.gov.uk/20140717032300/http://www.insolvencydirect.bis.gov.uk/insolvencyprofe ssionandlegislation/con_doc_register/compresc/compresc09.pdf. Accessed 20 Jul 2018 
UK Insolvency Service (2016a) A review of the corporate insolvency framework: a consultation on options for reform. May 2016. https://assets.publishing.service.gov.uk/government/uploads/ system/uploads/attachment_data/file/525523/A_Review_of_the_Corporate_Insolvency_Frame work.pdf. Accessed 20 Jul 2018

UK Insolvency Service (2016b) Summary of responses: a review of the corporate insolvency framework. September 2016. https://assets.publishing.service.gov.uk/government/uploads/syste m/uploads/attachment_data/file/578524/Summary_of_responses_26-10-16_Redacted.pdf. Accessed 20 Jul 2018

Waelde TW, Gunderson JL (1994) Legislative reform in transition economies: Western transplants: a short-cut to social market economy status? Int Comp Law Q 43:347-378

Watson A (1974) Legal transplants: an approach to comparative law. Scottish Academic Press, Edinburgh

Whittaker B (2015) A review of the Personal Property Securities Act 2009: final report. https://www. ag.gov.au/Consultations/Documents/PPSReview/ReviewofthePersonalPropertySecuritiesAct 2009FinalReport.pdf. Accessed 20 Jul 2018

Winship P (2016) An historical overview of UCC Chapter 9. In: Gullifer L, Akseli O (eds) Secured transactions law reform: principles, policies and practice. Hart Publishing, Oxford (chapter 3)

World Bank Independent Evaluation Group (2008) Doing Business: an independent evaluation, taking the measure of the World Bank-IFC Doing Business indicators. World Bank Publications, Washington, DC. http://documents.worldbank.org/curated/en/102811468157765042/pdf/449950PUB0 Box310evaluation01PUBLIC1.pdf. Accessed 20 Jul 2018 